\title{
Bir Peri Masalı Örneği: Ludwig Tieck'in Elfler Adlı Masalı Üzerine Bir İnceleme
}

\author{
A Fairytale Example: The Analysis Of Ludwig Tieck's Fairytale "The Elves"
}

\author{
Dr. Öğr. Üyesi Şenay KIRGIZ ${ }^{\text {DD } 1}$
}

\begin{abstract}
$\ddot{O} \mathbf{z}$
İlk kez 14. yüzyılda görülmeye başlayan peri masalları; içerisinde gizemi, büyüyü ve olağanüstüyü barındıran bir yazın anlayışına karşılık gelir. Gizem, insanoğlunda merak duygusunu tetikleyen ve bu bağlamda ilgi uyandıran başlıca olgulardan biridir. Peri masalı türü, içinde yaşanılan dünyanın gerçekliğe dayalı döngüsü içerisinde olağanüstüyü deneyimlemeye, gerçek yaşam düzleminin içerisine yerleştirilen bu olağanüstü deneyimlerden anlamlar çıkarmaya ve bu anlamlar doğrultusunda gizemin sir perdesini aralamaya hizmet eder. Türün görülmeye başlanmasından kısa bir süre sonra çok sayıda eserler verilmesinin ve bu denli ilgi görmesinin asıl sebebi de budur. İnsanoğlunun gizem karşısındaki ilgisi, Charles Perrault, Grimm Kardeşler ve Hans Christian Andersen gibi peri masalı yazarlarının popülarite kazanmasını sağlar. Her üç yazarın peri masalı (fairy tales) türündeki eserlerinin birçoğu (Kırmızı Başlıklı Kız, Uyuyan Güzel, Külkedisi, Pamuk Prenses v.b) ilk kez yayımlandığı yıldan günümüze değin hemen her çocuğun hayatında önemli ölçüde yer alır. Çocuklukta başlayan bu serüven hayat boyu sürer ve peri masalları artık yetişkinliğe erişmiş olan okurun ilgisini çekmeye devam eder. Çalışmada, peri masalı türü ekseninde Alman Romantik Dönemi yazarı Ludwig Tieck'in Elfler adlı masalı ele alınacak ve masal, peri masalı türünde sıklıkla yer alan öğeler ve karakterler bağlamında incelenecektir. Ayrıca çalışmada, kuramcıların peri masalı hakkındaki verileri esas alınacak ve masal, metin odaklı yöntem kullanılarak çözümlenecektir.
\end{abstract}

Anahtar Kelimeler: Elf, Ludwig Tieck, masal, peri masalı

Makale Türü: Derleme

\begin{abstract}
Fairytales which first started to be seen in 14th century correspond to an understanding of literature which embodies mystery, magic and the extraordinary. Mystery is one of the main characteristics which triggers curiosity in people and inspires interest in this respect. The fairytale genre serves to experience the extraordinary, to derive meaning from these extraordinary experiences placed within the real life and in accordance with these meanings to lift the veil of mystery within the cycle of the world that is lived in which is based on reality. This is the reason why numerous works appeared a short period after this genre emerged and there was such a great interest in the genre. The interest of mankind in mystery allowed fairytale writers such as Charles Perrault, Grimm Brothers and Hans Christian Andersen to gain popularity. A majority of these three writers' works in the fairytale genre (Little Red Riding Hood, Sleeping Beauty, Cinderella, Snow White, etc.) have taken a significant place in almost every child's life since the first time they were published until the present time. The adventure that began in childhood drives for lifelong and fairy tales continue to attract the reader who has reached adulthood. In the study, German Romantic Period writer Ludwig Tieck's fairytale The Elves will be dealt within the axis of the fairytale genre and the genre will be analyzed with respect to the characteristics and characters which frequently appear in fairytales. Besides in the study will be predicated on the theorists' datas about the fairytale and the tale will be analysed to use work-immanent method.
\end{abstract}

Keywords: Elf, Ludwig Tieck, fairytale, fairy story

${ }^{1}$ Sivas Cumhuriyet Üniversitesi, Edebiyat Fakültesi, senay_kirgiz@hotmail.com

Atıf için (to cite): Kırgız, Ş. (2019). Bir Peri Masalı Örneği: Ludwig Tieck’in Elfler Adlı Masalı Üzerine Bir İnceleme. Afyon Kocatepe Üniversitesi Sosyal Bilimler Dergisi, 21(3), 792-807. 
Paper Type: Review

\section{Giriş}

Peri masalı, tıpkı olağanüstü ve hayvan masallarında olduğu gibi geniş ölçüde bir okur kitlesine sahiptir. İnsanoğlunun kendinde olmayana karşı duyduğu merak, bu tür masallara karş1 ilgi duyulmasını sağlar ve okur, yaşamın tüm monotonluğuna karşın, içerisinde perilerin, cinlerin, elflerin, cücelerin ve sihirli nesnelerin bulunduğu olağanüstü bir dünyayı deneyimleme arzusu duyar. Peri masalı da bu arzu doğrultusunda ortaya çıkan türlerden biridir. Peri masallarının her kesim okuyucuda bazı benzer hisler uyandırma gibi bir özelliği vardır. "Uyuyan Güzel" masalında prensin, perinin lanetini bozması ile sevinen okur, "Pamuk Prenses" de kötü kalpli kraliçeye sinirlenir ve Külkedisinin prens ile evlenmesine heyecanlanır. Bu hisler, hemen her okurda ortak olarak görülmektedir.

Peri masalı türü, Alman edebiyatında erken Romantik Dönem ile birlikte görülür. Märchen olarak da adlandırılan türün, ilk temsilcileri Jakob ve Wilhelm Grimm adlı kardeşlerdir. Şehir şehir gezip yaklaşık olarak yetmiş adet masalı derleyen Grimm kardeşler, peri masalının Almanya'da gelişmesi adına önemli çabalar sarf etmişlerdir. Grimm kardeşleri takiben Novalis takma adını kullanan Georg Philipp Friedrich Freiherr von Hardenberg ve Johann Wolfgang von Goethe gibi yazarlar peri masalı türünde eserler vermeye başlar. Alman yazar Johann Ludwig Tieck, Fransız şair ve yazar Charles Perrault'un masallarını derleyerek başladığı Märchen türüne, önemli ölçüde katkı sağlar. Bu bağlamda bu çalışmada, Johann Ludwig Tieck'in 1812 yılında üç cilt halinde yayımladığı Phantasus adlı eserinin birinci cildinde yer alan Die Elfen (Elfler) adlı masalının, peri masalı türünün özelliklerinden yola çıkarak incelenmesi amaçlanmıştır. Ayrıca çalışmada, peri masalı türü ele alınacak ve bu doğrultuda türde yer alan ögeler ve karakterler dikkate alınarak, Elfler adlı masaldaki yansımaları irdelenecektir.

\section{Ludwig Tieck}

Alman Romantik Dönemi'nin önemli yazarlarından olan Johann Ludwig Tieck, 31 Mayıs 1773 yılında ailesinin ilk çocuğu olarak Berlin'de dünyaya gelir. Dört yaşında okumayı öğrenen Tieck, 1782 yllında Berlin'de bulunan Friedrichwerdersche Gymnasium'a (Friedrichwerdersche Lisesi) gider ve orada üstün bir başarı kazanır. 1791 yılında Berlin'den ayrılarak Halle'ye gider ve üniversite giriş yeterliliğini kazanarak 1792 yılında die Universität Halle'ye (Halle Üniversitesi) girmeye hak kazanır. Babasının en büyük arzusu olan İlahiyat eğitimini alan Tieck, bunun yanı sıra Antik Roma Edebiyatı ve Felsefe üzerine de eğitim görür. 1792 yılında Halle Üniversitesi'nde yarım bıraktığı eğitimine, aynı yıl Universität Göttingen'de (Göttingen Üniversitesi) devam eder. Orada kütüphanelerde çok vakit geçirir ve Cervantes, Shakespeare gibi yazarlardan etkilenir. Aynı yıl Der Abschied (Veda) adlı kısa dramasını ve Das grüne Band (Yeşil Band) adlı hikâyesini tamamlar ve Die Geschichte des Herrn William Lovell'i (Bay William Lovell'in Hikâyesi) tasarlar. Böylece Göttingen Edebiyat Topluluğu'nun üyesi olur (Gebhardt, 1997: 9-11).

Bundan sonra Tieck, erken Romantik Dönemi yazarı olarak edebiyat sahnesinde yer alır ve eserler vermeye devam eder. Ludwig Tieck'in yazarlık kariyerinin dönüm noktası belki de "genç yazar ve eleştirmen olan August Wilhelm ve Friedrich Schlegel ile arkadaşlık kurması ve Jena'da romantik olarak adlandırılan yazar ve eleştirmen çevresine dâhil olması için davet edilmesi" (Stockinger und Scherer, 2011: 6) ile gerçekleşir. Ailesi ile Jena'ya taşınan Tieck, Johann Gottlieb Fichte, Karl Wilhelm Friedrich Schlegel, Georg Philipp Friedrich Freiherr von Hardenberg (Novalis), August Wilhelm, Friedrich Schelling, Friedrich Schleiermacher, Johann Gottfried Herder gibi yazar, şair ve filozoflardan oluşan Erken Romantik Dönemi'nin önemli yazarlarından biri haline gelir.

Steinmetz, fantastik yazın üzerine yaptığı ayrıntılı incelemelerinin yer aldığ Fantastik Edebiyat isimli çalışmasında, Märchen (peri masalı) türünün Alman Edebiyatında gelişim 
göstermesinde, Ludwig Tieck'in yadsınamaz katkıları olduğundan bahseder. Märchen'e merak duyan Tieck'in ilk olarak Perrault'un Peri Masalları'nın bazı versiyonlarını tasarlamaya çalıştığını ya da Melusine'nin öyküsünü yeniden ele aldığını belirtir. Steinmetz'e göre Tieck'in olağanüstüne duyduğu ilgi, Skakespeare'in Fırtına ve Bir Yaz Gecesi Rüyası adlı eserlerine dayanır. Her ne kadar Tieck, ilk olarak daha önce yapılmış eserler üzerine çalışsa da, kendi kişisel takıntılarını peri masalı âlemine uyarlayarak, farklı bir yönelim göstermiş olur. Steinmetz, Tieck'in Märchen 'inin çoğunlukla bireysel hayallerden, insanın içine işleyen hayal kırıklıklarından beslendiğini ifade eder. Tieck'in peri masallarında, ülkesini terk etmiş ve kendisini yabancılık ortamında bulmuş bir kişi söz konusudur ve o kişi çoğunlukla engin bir ormanın bağrına atılır. Bu 1ssız ormanda perilerle ve elflerle karşılaşır. Kahraman, büyük bir şaşkınlık içerisinde, tüm hayatı boyunca etkisinden kurtulamayacağı olağanüstü bir evrenle temasa geçer. Ama olağanüstü, Steinmetz'e göre çoğunlukla ölüme yakın durur (Steinmetz, 2006: 62-63).

\section{Peri Masalı Üzerine}

Peri masalı (fairy tales), yaygın olarak halk masalı (folk tale) türü ile karıştırılır ve her iki tür birbirlerinin yerine kullanılır. Bu durum Propp'un "Bir masalı oluşturan parçaların hepsi hiçbir değişikliğe uğratılmadan başka bir masala aktarılabilir" (Propp, 1987: 17) tezine örnek teşkil eder. Her iki terimin birbirlerinin yerine kullanılması terminolojik açıdan yanlış anlaşılmalara sebebiyet verir. Bu nedenle halk masalı ve peri masalını birbirlerinden ayırmak ve tarihsel farklılıklarını ve karakteristiklerini sınıflandırmak gerekir. Halk masalı, yapısı, karakterleri, konusu ve yaşı ile peri masalından farklıdır. Halk masalında karı, koca, köylüler, ahlaksız hırsız, nadiren doktor, avukat, rahip, vaiz gibi aşina olunan dünyanın karakterleri yer alır. Halk masalının tipik konusu bir insanın diğer bir insanın parasını, eşyasını ve onurunu çalmasıdır. Daha ötesi, halk masalı genellikle mutlu sonla bitmez (Bottingheimer, 2009: 4). Oysa peri masalının genel olarak mutlukla biten sonu, okurunun yüzünde kocaman bir gülümseme bırakır. Peri masalı ile ilişkilendirilen diğer bir tür ise olağanüstüdür. Tzvetan Todorov, Fantastik: Edebi Türe Yapısal Bir Yaklaşım adlı çalışmasında; peri masallarının çoğunlukla olağanüstü türü ile ilişkilendirildiğini belirtir. Gerçekte peri masalının olağanüstünün bir çeşidi olduğunun altını çizen Todorov, peri masalında doğaüstü olayların-ne yüzyıllık uyku, ne konuşan kurt ya da perilerin sihirli güçleri olsun- hiçbir sürpriz duygusu uyandırmadığını imler. Ona göre peri masallarının özelliği, doğaüstü konumundan değil, belirli bir yazı anlayışından ileri gelir (Todorov, 2004: 59).

Peri masalı türünün hangi ülkede ortaya çıktığı konusunda tam bir fikir birliği bulunmamaktadır. Bazı kaynaklar peri masalının kökeninin Fransa olduğunu imlese de, türün Alman Romantik Dönemi'ne dayandığına dair ifadeler de bulunur (Bkz. Steinmetz, 2006). Kaynağına inmek gerekir ise; peri masalı, ilk kez 14. Yüzyılda Boccaccio'nun Decameron'u yayımlaması ile yazın sahnesine çıkar. Daha sonra peşi sıra peri masalı türünde eserler görülür. Fransiz yazar Charles Perrault'un 1697'de Contes de ma mère l'Oye'yi (Anne Kazın Masallart) yayımlaması ile peri masalı türünden bahsedilmeye başlanır. Alman masal yazarları olan Grimm Kardeşler'in Kinder- und Hausmärchen (Çocuk ve Ev Masalları) (1812-15) ve Danimarkalı masal yazarı Hans Christian Andersen'in ilk İngilizce çevirisi olan ve 1846 yılında yayımlanan Fairy Tales (Peri Masallarl) eserleri ile birlikte popülarite kazanır (Jones, 2002: 1-2). Bundan sonraki süreçte bu yazarların masalları peri masalı olarak anılmaya başlanır. Bu bağlamda, Nesrin Duman, "Peri Masallarının Orijini” adlı çalışmasında, Grimm's Fairy Tales'(Grimm'in peri masalları) ya da „Andersen's Fairy Tales' (Andersen'in peri masalları) olarak adlandırıldığına ve Türkiye'de Batı kaynaklı olan bu kavramın Türkçeye de yerleştiğini, ister batı ister doğu kaynaklı olsun benzer tipteki hikâyeler için peri masalı ifadesinin kullanıldığını belirtir (Duman, 2018: 68-69).

Bazı kaynaklar peri masalının Fransa kökenli olduğunun altını çizse de Jean-Luc Steinmetz, peri masalının çıkış yerinin Almanya olduğunu önerir. Steinmetz, Märchen diğer adıyla peri masalının Almanya'da ortaya çıkmasını Alman Romantik Dönemi'ne dayandırır ve 
Alman Romantik Dönemi'nde peri masalının gerçek ve tipik anlamda ilk kez görülmesini Herder'e bağlar ve olağanüstünün önemli bir kısmını oluşturan ve peri âlemi ile insan âlemini bir arada yaşatan şeklinde tanımladığı peri masalına ilgi duyan ilk Alman Romantiklerin Goethe ve Novalis olduğunu ifade eder. Goethe'nin Die neue Melusine (Yeni Melusine) adlı eserini buna kanıt gösterir. Steinmetz, peri masalına evrensel bir boyut kazandırdığını düşündüğü Novalis'in, peri masalını "bir müzikal fantezi, bir rüzgâr arpının armonik süitleri, doğanın bizzat kendisi gibi olağanüstü şeylerin bütünü” olarak düşündügünü belirtir. Steinmetz ayrıca, , mavi çiçek izleğinin yer aldığı Heinrich von Ofterdingen romanında peri masalı türünün özelliklerinin aç1kça görüldügünü belirtir (Steinmetz, 2006: 61).

İngiliz filolog ve yazar John Ronald Reuel Tolkien, peri masallarının kaynaklarına kadar indiği Peri Masalları Üzerine adlı çalışmasında; peri masallarının komik ve gülünesi yapıtlar olmadığının altını çizer. Tolkien'e göre, bir peri masalı, asıl amacı yergi, macera, ahlak veya fantezi olsun, Periler Diyarından bahseden ve onu kullanan bir masal türüne karşılık gelir. Tolkien, Periler Diyarı kavramına en yakın olarak "sihir" kelimesinin karşılık geldiğini niteler. Bu sihrin en çalışkan ve bilimsel sihirbazın kaba aletlerinden çok uzakta, garip bir ruh hali ve gücün sihri olduğunu belirtir ve bu masallardaki başat koşulun masalda bir parça yergi yer alsa bile- sihrin kendisi ile dalga geçilmemesi, aksine ciddiye alınması olduğunu yineler (Tolkien, 1999: 21-22).

Ayrıca Tolkien, peri masallarının aslında çok eski zamanlara ait olduğundan bahseder ve peri masalının yaratımında buluş, miras ve yayılma olarak adlandırdığı üç önemli bağımsız koşulun varlı̆̆ını sorgular. Tolkien'e göre buluş, üç koşul arasında en önemli, temel ve gizemli olanıdır. Buluş, peri masalının mucididir, onu öyküleyen kişidir. Yayılma, öyküye kaynaklık eden mekândır. Miras ise, insanoğlunun atalarından olan bir mucide rastlamasıdır. (Tolkien, 1999: 34-35).

Tolkien, perilerin yaşadığı ülke ya da bölge olarak tanımladığı Periler Diyarı sakinlerinin sadece periler ve elflerden oluşmadığını savunur. Cüceler, cadılar, ifritler, devler, ejderler ve başka bir sürü şeyi de barındırdığını dile getirir (Tolkien, 1999: 20). Emrah Doğan, "Türk Sinemasında Masal Uyarlamaları ve Vladimir Propp'un Halk Masalları İşlevlerinin Pamuk Prenses Ve Yedi Cüceler (1970) Filminde Çözümlenmesi” adlı çalışmasında, olağanüstü durum ve olayları yine olağanüstü kahramanlara bağlayarak anlatan masalların, iyilik-kötülük, doğruluk-haksızlık-adalet-zulüm, alçakgönüllülük-kibir gibi ikircikli bir tarzdaki anlatım biçimleri olduğundan bahseder. Doğan, masallarda karakterlerin ulaşılması güç durumların üstesinden gelmesinin, yer ve zaman kavramlarının belirsizliğinin ve toplumun her tabakasından ve toplumsal gerçeklikte yaşaması imkânsız cinler, periler, devler gibi karakterlerden oluşmasının ve hatta hayvanlara insan karakterleri yüklenip konuşturulmasının toplumsal gerçekliğin zıttı bir duruma karşılık geldiğini ve masallarda pembe bir gerçeklik sunulduğunu belirtir (Doğan, 2018: 56). Peri masallarında olağanüstü koşullarda yer alan peri, cadı, ifrit, cüce, dev, ejderha ve elf gibi tüm karakterler, okura gerçek yaşamında karşılaşmasının imkânsız olduğu, büyülü bir atmosfer sunar. Başka bir ifade ile "peri masallarl yardımsever figürleriyle, asil kral ve kraliçeleriyle popüler olsa da, aynı zamanda cadılar, canavarlar, troller ve diğer korkunç yaratıklarla da doludur. Bazı masal uyarlayıcıları, birçok çocuğun özellikle hikâyenin geçtiği güvenli ortamındaki tehlikeli durumlardan keyif aldıklarını unutarak masallardaki korku, kötülük ve şiddeti minimize ederler" (Duman, 2018: 71).

Tolkien'in peri masallarını modernleşme hareketi olarak betimlemesinin nedeni; modern çağ okurunun peri masallarında yer alan büyülü atmosferden heyecan duymasıdır. Kuşkusuz masalın okurda yarattı̆̆ bu etki, masalın kolektif bir bilinç ürünü olmasından kaynaklanır. Ahmet Sarı ve Cemile Akyıldız Ercan, Masalların Psikanalizi adlı çalışmalarında, masalın kolektif bilinçdışına olan hizmetinden şu şekilde bahseder: "İnsanlık tarihini oluşturan tüm verilerin, kültüre ait verilerin, uygarlı̆̆ uygarlık yapan verilerin insan belleğinden, zihninden çıktı̆̆ dikkate değerdir. Kökende bir masal, anlatanın, bir anlatıcının her zaman olduğu bu tarz kültür kuruculuk eylemlerinde anlatıcı (narratör) ister sözlü, ister yazılı bir 
metnin taşıyıcıllı̆ıın yapsın, zihninde yer etmiş bu kültür arketipini, kültürü kültür yapan şeyi bir şekilde anlatımlartyla insanlara aktarır" (Sarı ve A. Ercan, 2008: 29). Alıntı, kültür öğelerinin masallar yoluyla insanın zihnine kodlandığına dikkat çeker. Analitik psikolojinin kurucularından olan Carl Gustav Jung'un, insanoğlunun binlerce yıllık deneyimlerinin katmanlaşarak, sonrasında gelen her nesle kodlandığını belirttiği kolektif bilinçdışı kavramı, masalların sözlü ya da yazılı olsun her nesilde aynı kültürel farkındalık oluşturduğu düşüncesini kanıtlar niteliktedir. Ali Osman Öztürk, "Oğuz Tansel Masallarının Derin Kökleri Üzerine Bir Örnek Mavi Gelin Masalı" adlı çalışmasında masal hakkında "Masallar sözlü kültürün ürünüdür çoğu kez. Batı'da ilk kez 19. yüzyılda Romantik dönemde Grimm Kardeşler Jacob (1785-1863) ve Wilhelm (1786-1859) masallar derliyorlar. Bu iki akıll, bilge ve çalışkan insan sayesinde Batı masalları derleniyor ve bugün bildiğimiz çoğu masal onların sayesinde bize ulaşlyor. Doğu'da bizler sözlü kültürün ürünleriyiz. Anadolu'da sayısız masal anlatılır ve bu masallar yaşadıkları konum gereği çok kültürlüdür" (Öztürk, 2017: 316) şeklinde bir açıklama yapar. Alıntı, masalın çok kültürlü yapısına gönderme yapar.

Bruno Bettelheim Büyünün Yararlart-Peri Masallarının Anlam ve Önemi adlı çalışmasında yer alan "Masal-Mit (İyimserlik-Köütmserlik)"adlı yazısında, Jungcu ruhçözümlemecilerin "bu öykülerdeki kişilerin ve olayların, ilk örneksel ruhbilimsel olgulara uyum sağladıklarını, böylece bu olguları temsil ettiklerini ve daha yüksek bir benlik düzeyi elde etme gereksinimini -kişisel ve ırksal bilinçdışı güçler kişi için ulaşılabilir oldukça sağlanan bir içsel yenilenmeyi simgesel olarak gösterdiklerini vurgula" (Bettelheim, 1999: 90, İçinde: Sarı ve A. Ercan, 2008: 23) diklarından bahseder.

\section{Ludwig Tieck: Elfler}

Alman Romantik Dönemi'nin önemli yazarlarından olan Ludwig Tieck'in, 1812 yılında "bir kısmı daha önce yayınlanmış olan masal, hikâye, dram ve novellerini üç cilt" (Aytaç, 1983: 237) halinde yayımladığ 1 Phantasus adlı eserinin birinci cildinde yer alan Die Elfen (Elfler) masalı, merkeze Marie adlı küçük bir kız çocuğunu alır. Marie'nin ailesi yaşadıkları bölgenin kontunun sahip olduğu topraklarda, otları biçen işçileri denetleme işiyle meşguldür. Ailesi işe gittiğinde yalnız kalan Marie vaktinin çoğunu, komşunun oğlu olan yegâne arkadaşı Andres ile oyun oynayarak geçirir. Marie ile Andres'in en çok zevk aldıkları oyun, evlerinin yakınında bulunan alanda koşup yarış yapmaktır. Marie'nin ailesi Andres'e kendi evlatları kadar güvenir, fakat anne Brigitta'nın tek bir endişesi vardır, o da çocukların evlerinin yakınında bulunan ormanlık alana gitmeleridir. Bu yüzden tarlaya gittikleri her gün Marie ve Andres'i: "Evden fazla uzaklaşmayın ve sakın ha ormana girmeyin; babayla ben tarlalara gidiyoruz" (Tieck, 2004: 6) şeklinde uyarır. Nitekim derenin karşısında bulunan bölge oldukça tekinsizdir. Orada kimin yaşadığı konusunda hiçbir bilgi sahibi olmayan halk, yıllardır kendi aralarında farklı hikâyeler anlatır. Dışarıdan oldukça kurak ve issız görünen bölgede, son derece tehlikeli insanların yaşadığına dair bir düşünce yaygındır.

Ailesi tarlaya gittikleri bir gün yalnız kalan Marie, Andres ile birlikte ormanın içine doğru koşmaya başlar. Marie, rakibini yenmek için derenin etrafından dönmeyi yeğler, çünkü küçük kız oraya doğru yönelmenin kestirme olabileceğini düşünür. Koşarken önüne bir köpek çıar. Önceleri köpek konusunda tedirginlik yaşayan Marie, zamanla köpek ile oynamaktan hoşnut olmaya başlar. Öyle ki derenin karşı tarafina geçip, annesinin kendisini kesinlikle yaklaşmaması konusunda uyardığı bölgeye girdiğinin farkına varmaz. Dışarıdan oldukça kurak ve bakımsız görünen bölge, gerçekte eşsiz bir tabiata sahiptir. Küçük kız daha önce böylesine mükemmel bir yer görmemiş olmanın şaşkınlığı içerisindedir. Üstelik etrafta pırıldayan güzel çocuklar oyun oynamaktadır. Marie şaşkınlık içerisinde etrafı izlerken, yanına son derece sevecen küçük bir çocuk yaklaşır. Adı Zerina olan çocuk, Marie ile yakından ilgilenir ve bu eşsiz güzellikteki bölgeyi gezdirmeye başlar. İki küçük çocuk arasında kuvvetli bir bağ oluşur. Yaptıkları gezinti esnasında Marie, hayatı boyunca hiç tecrübe edemeyeceği oranda olağanüstü deneyimler yaşar. Sonsuza kadar yaşamak istediği bu bölgede, geçirmek zorunda olduğu zaman kısıtlıdır, çünkü kral bölgeyi ziyaret etmek üzere haber göndermiştir ve bir ölümlünün orada 
yaşaması mümkün değildir. Bir günden daha az sürede orada bulunan Marie, kendisine verilen tılsımlı bir yüzük sayesinde yaşadığı yere döner.

Geri döndüğünde hiçbir şey bıraktığı gibi değildir. Evine girdiğinde ailesinin oldukça değiş̧iğini fark eder. Ailesi de ilk başta Marie’yi tanımaz. Marie büyümüş ve çok güzel bir genç kız olmuştur. $\mathrm{O}$ anda Marie, kaybolmasının üzerinden yedi yıl geçtiğini anlar. Zerina'nın diyarında geçirdiği saatler, nasıl olur da yedi yıla eş değerdir? Bu durum Marie için anlaşılmaz olur. Marie, Zerina'ya gördükleri konusunda kimseye bir şey söylememeye söz vermiş̧ir. Bu nedenle, koşarken kaybolduğunu ve iyi bir ailenin kendisine yedi yıl boyunca baktığını anlatır. Marie güzelliği ve yeteneği ile herkesin dikkatini çeker. Genç kı, sihirli bir değnek değmişçesine yetenekler ile donatılmıştır. Kendisi gibi büyüyüp, serpilen Andres ile evlenen Marie, çocukken yaşadığı olağanüstü deneyimin etkisinden sıyrılır ve normal hayatın akışı içerisinde yaşamına devam eder. Bir kız çocuğu dünyaya getirir ve adını Elfriede koyar. Elfriede, normal bir bebekten beklenemeyecek ölçüde hızlı gelişim gösterir. Bir yaşı dolmadan akıcı bir şekilde konuşur, çok erken yürür. Dikiş de dâhil olmak üzere tüm ihtiyaçlarını kendisi görür. Elfriede açısından daha ilginç olan ise, annesi ve babası başta olmak üzere, hiç kimse ile iletişim kurmak istememesidir. Oldukça yalnız olan küçük kız, tüm gününü evlerinin arkasındaki bahçede geçirir. Bir gün Marie, Elfriede'nin üzerini değiştirirken çok değerli bir kolye taktığını görür. Marie kolyeye aşinadır, çünkü kolyeyi, küçükken esrarengiz bölgede yaptığı gezi sırasında görmüştür. Bu durumdan şüphelenen Marie, Elfriede'yi takip etmeye başlar. Küçük kız arka bahçeye yöneldiğinde onu gizlice gözler ve arka bahçede Zerina'yı görür. Kızı Zerina ile konuşmaktadır. Artık yetişkin olan Marie, kendisinin de yaşadığı bu deneyimini ve Zerina'ya verdiği sözü unutur ve olanları Andres'e anlatır. Böylece Zerina ölümlülere güvenmemesi gerektiğini acı bir şekilde öğrenir. Kral, bu duruma çok sinirlenir ve derenin karşısında yaşayan halkını toplar ve bölgeden sürgün eder. Eşsiz güzellikteki bölge, şimdi gerçekten kurak ve kimsesizdir. Bu duruma çok içerleyen Elfriede, bir çiçek gibi solar ve ölür. Sebep olduğu trajedi karşısında vicdan azabı çeken Marie de kızının ardından yaşama veda eder. Bu hali ile Elfler masalı, mutlu sonla biten birçok türdeşinden ayrılır. Tieck, masalını mutsuzluk, trajedi ve ölüm ile tamamlar. Özet şeklinde anlatılan masal, çalışmanın sonraki bölümünde peri masalı türünün özellikleri ve peri masalında yer alan karakterler bağlamında irdelenecektir.

\section{Ludwig Tieck'in Elfler Adlı Masalının İncelenmesi}

\subsection{Marie Elf Diyarı'nda}

Ludwig Tieck'in Elfler adlı masalını, peri masalı türü ile ilişkilendirebilecek ilk ve belki de en belirleyici ölçüt, Marie'nin olağanüstü deneyimlerini yaşadığı derenin karşı tarafindaki karanlık bölgedir. Zerina'nın Marie'nin kim olduklarına dair yönelttiği sorusuna karşın, elf oldukları yanıtını vermesi ile Marie'nin yaşadığı gerçek dünyanın hemen yanı başında konuşlanan doğaüstü bir dünya olduğunu söylemek mümkündür. Nitekim Elf Diyarının-ki Zerina'nın, elf olduğu itirafından ve Tolkien'in Elf Diyarı kullanımından sonra yaşadıkları bölgeye Elf Diyarı demek mümkündür- sakinlerinin elfler, periler, cüceler, duvar halısında dans eden ateşten figürler, kuşları andıran kanatlı bekçiler olması, ele alınan masalın, peri masalı türünün tipik karakterlerine sahip olduğunu kuvvetlendirir.

Elf Diyarı, dışarıdan kurak, çorak ve kimsesiz gibi görünür. Masalda yer alan: "Dünyanın en güzel, en renkli bahçesinin içindeydi; laleler, güller ve zambaklar renk renk ışık saçmaktaydı adeta; mavi ve altın sarısı-kırmızı kelebekler çiçeklerin arasında kanat çırpıyor, meyve ă̆açlarına asılı parlak kafeslerde rengârenk kuşlar cıvll cıvıl ötüyordu; ve çocuklar... Beyaz kısa elbiseler içinde, sarı saçları rüzgârda dalgalanan, gözleri ışıl ışıl çocuklar... Neşeyle gülüp oynamaktaydılar; bazısı küçük kuzularla oynuyor, bazısı kuşları besliyor, ya da çiçek toplayıp birbirine veriyorlardl, ve bazıları da kiraz, üzüm ve kırmızı kırmızı kayısılardan yemekteydi. Görünürde hiçbir kulübe yoktu. Bunun yerine kocaman, çok güzel bir ev vardı" (Tieck, 2004: 11-12) betimlemesi, bölgenin tabiat olarak her ne kadar eşsiz güzellikte olsa da, 
insanlara kapalı bir alan olduğunun altını çizer. Alıntı, Tolkien'in Elf Diyarının görünmezliğini yabani bir çuhaçiçeğinin ardında saklanmaya ya da bir otun ince uzun yaprağının ardına gizlemeye dönüştüren bir modernleşme (Tolkien, 1999:15) olduğu düşüncesine örnek teşkil eder.

Tarlaya denetime giderken Brigitta ve eşi Martin'in arasında geçen diyaloglar, bu duruma örnek teşkil eder. Martin'in eşi Birgitta'ya yönelttiği: “Dönüp bir baksana, böylesine canlı bir manzaranın ortasında ne kadar da karanlık ve iç karartıcı duruyor; rengi soluk köknar ăgaçlarıyla arkalarındaki dumanl kulübeler, harap olmuş ahırlar... Oradan geçerken bile hüzünlü aklyor" (Tieck, 2004:8) şeklindeki cümle, Elf Diyarının insanların gözünde ne denli karamsar bir imaj yarattı̆̆ının göstergesidir. Brigitta'nın “insan oraya yaklaşınca kederleniveriyor, hem de ortada hiçbir şey yokken. Orada ne tür insanlar oturuyor olabilir acaba? İçlerinde şeytani duygular taşır gibi neden kendilerini bizlerden ayırıyorlar?" (Tolkien, 2004: 8) şeklindeki sözlerinin devamında dile getirdiği: "Belki sadece utançlarından fakirliklerini saklamak isteyen zavall insanlardır. Bundan dolayı kimse onları suçlayamaz; sorun şu ki, kiliseye gitmiyorlar, nasıl yaşadıklarını, neyle geçindiklerini kimsecikler bilmiyor; küçük bahçeleri tamamen çorak, onları beslemesi mümkün değil; ve hiç tarlaları yok" (Tieck, 2004: 8-9) düşüncesi ise, Elf Diyarı sakinlerinin, derenin karşı tarafında yaşayan komşuları ile aralarına keskin bir mesafe koyduklarının ispatıdır. Bu mesafenin sınırlarını hiçbir suretle bozmayan Elf Diyarı sakinleri, ölümlüler ile yakın ilişkiler kurmamakta ısrar ederler. Derenin karşı tarafında yaratılan bu gizem, insanlar açısından büyük merak uyandırır. Brigitta ve Martin arasında geçen "dediklerine göre eski, yırtık pırtık giysiler giyen bu kadınların kucaklarında a en az kendileri kadar pis ve çirkin çocuklar vardl; ve de evin etrafinda koşuşturan köpekler... Hatta bir gece, derenin üstündeki köprüden geçip kulübeye giren dev gibi bir adam görülmüştü ve karanlıkta hareket eden türlü türlü şekiller...” (Tieck, 2004: 9) şeklindeki diyalog, aslında bazılarının bölgeye yaklaşma teşebbüsünde bulunduğuna ve gördükleri karşısında tereddüt duyduklarına işaret eder. Doğaüstünün, yetişkin bir bireyin mantık sınırlarını aşması durumuna örnek teşkil eden bu durum, diğerleri tarafından şehir efsanesi olarak kabul görür. Anlatıdaki en dikkat çekici detay, küçük bir kız çocuğu olan Marie'nin Elf Diyarı tasviri ile bölgeye bakmaya cesaret gösteren yetişkinlerin anlattıklarıdır. Elf Diyarı, gizli kapılarını yalnızca çocuklara açmaktadır. Marie ve kızı Elfriede'yı özel kılan, Marie'nin Elf Diyarı'nı bizzat ziyaret etmesi, Elfriede'nin ise küçük elf Zerina tarafindan ziyaret edilmesi farkı dışında, bu olayları yaşadıklarında çocuk yaşta olmalarıdır. Alman masal derlemecileri Grimm Kardeşlerin Hänsel und Gretel (Hansel ve Gretel) ve Rotkäppchen (Kırmızı Başlıklı Kız) masallarında, Danimarka'lı masal yazarı Hans Christian Anderson'un Den Lille Pige med Svovlstikkerne (Kibritçi Klz) masalında olduğu gibi, Ludwig Tieck de Elfler adlı masalında küçük bir çocuğu başkarakter konumuna getirir. Marie, Kırmızı Başlıklı Kız ve Hansel ve Gretel örneğinde olduğu gibi, kendisine ebeveynleri tarafından yasaklanan gizemli bölgeye yönelim gösterir. Gizemli, olağanüstü, sihirli, büyülü bir bölge, peri masalları açısından başat ögedir. Kırmızı Başlıklı Kız masalında insan yiyen kurt, Hansel ve Gretel'de ormanda kaybolmuş çocukları şekerden yapılmış evi ile kandıran, onları besledikten sonra pişirip yiyen yaşlı cadı gibi demonik özellikteki karakterlerden farklı olarak, Elfler masalında Marie, zararsız, iyi ve sevecen karakterler ile karşılaşır.

Marie, aynı zamanda İngiliz yazar Lewis Carroll'un ünlü romanı Alice in Wonderland' in (Alice Harikalar Diyarında) başkarakteri Alice ile de benzerlik gösterir. Alice, gördügü garip (!) bir tavşanın peşinden giderek Harikalar Diyarına, Marie ise, Zerina'nın köpeğinin peşine takılarak köknarlarla kaplı derenin diğer tarafındaki Elf Diyarına ulaşır.

Tüm bu ifadeler akıllara, Kırmızı Başlıklı Kızı, Hansel ve Gretel'i, Alice'yi ve Marie'yi özel kılan ve bu beş küçük karaktere olağanüstü deneyimi yaşatan tılsım nedir? Sorularını getirir. Bu soruların yanıtı, peri masallarının da dâhil olduğu birçok masalın çocuk okurlara hitap etmesidir. Meryem Nakiboğlu, "Hermann Hesse'nin “Augustus" Masalında Masal Öğeleri Ve Propp'a Göre Çözümlenmesi” adlı çalışmasında bu savı destekler ifadeler kullanır. 
Nakiboğlu, çocukların gizemli iç dünyalarının en iyi şekilde masallar yoluyla görüldüğünü açıklar. Masallarda sınır olmadığının, dilediğiniz yere dilediğiniz anda gidilebildiğinin, tüm hayvanlarla konuşulabileceğinin, devlerle seyahat edilebileceğinin, perilerle karşılaşabilineceğinin, olağanüstü olaylar yaşanılabileceğinin altını çizen Nakiboğlu, çocukların, yetişkinlerin ulaşamayacağı gizemlere masallar yoluyla ulaşabileceğini ifade eder. Ayrıca, masalların eğitici özelliklerde olduğunu ifade eder. Masalların, çocukların düş gücünün gelişmesine ve düşünce ufuklarının açılmasına yardımcı olduğunu vurgular (Nakiboğlu, 2016: 243). Benzer olarak, Hikmet Asutay, "Çocuk ve Gençlik Yazınında Fantastik Kavramı" adlı çalışmasında; çocuk için bebeklikten başlamak üzere, gerçek ile düş arasındaki sınırın yok denecek kadar geçişken olduğunu ve çocukların her iki boyutu da algıladığını imler. Çocukların henüz soyut kavram bilinci oluşmadığından bahseden Asutay, bu nedenle hayal ürünü olan her bir şeyin çocuk açısından, duyularıyla ulaşılabilen nitelikte olduğunu belirtir. Çocuğun oyun ile gerçeği büyüdükçe ayırt ettiğinin, gerçek ile oyunun sınırlarını belirleyebildiğinin, ayrımını yapabildiğinin altını çizer (Asutay, 2014: 642). Bu bağlamda, Marie'nin çocuk iken yaşadığı olağanüstü deneyimi, büyüdükçe unutması, onun geniş hayal dünyasından sıyrılarak giderek gerçeklik algısına daha da yakınlaşmasından kaynaklanır. Bu durum, okurda Marie'nin yaşadıklarının gerçek olduğu veya onun çocuk iç dünyasının ürünü olduğu konusunda ikircikli bir tereddüt yaratır. Fakat bir peri masalının gerçekliğe ne oranda yakın olduğu şüphesine karşı olarak Tolkien, gerçek bir peri masalının, doğru sunulması gerektiğini önerir. Peri masalının mucizeler ile uğraştığını belirten Tolkien, içinde geçen tüm öykünün uydurma ya da hayal ürünü olabileceğini akla getirecek herhangi bir çerçeve ya da mekanizmanın hoş görülemeyeceğini imler (Tolkien, 1999: 26). İşte bu noktadan hareketle Tieck, okuruna kurguladığı peri masalının gerçekliğini sorgulatma imkânı vermez ve devreye diğer bir çocuk karakter olan Elfriede'yi sokar. Elfriede'yi da Zerina ile dost k1lar. Zerina ile ikinci kez karşılaşan okur, okuduklarının hayal ürünü olabileceği konusundaki endişelerinden sıyrılır.

\subsection{Küçük Elf Zerina}

Elf, peri masallarında çoğunlukla kullanılan bir kavramdır. Elf kavramı İskandinav, Anglo Sakson, Galler, Kelt, İskoçya, İrlanda mitolojilerine, Cermen, Afrika ve Norveç halk kültürlerine kadar uzanan geniş bir yelpazede yer alır. Kuzey kültürüne ait olan bu yaygın halk inanışı figürü, bölgelere göre farklı kelimeler şeklinde kullanılır. Álfr, Älf, Alb, Elb, Elf, Elfen (çoğul), Elfin, Ellyll, Ellyllon (çoğul), Elv, Elves (çoğul), Ylf, Ylfe (çoğul) bu kullanımlardan bazılarıdır.

Theresa Bane, mit, efsane ve folklordaki yaratıklar ve canavarlar üzerine yaptığ ansiklopedik derlemesinde; elf kavramının varyasyonları olarak ayrıca Fary, Fay, Frée, Huldrafolk, Mannikin, Ouph ve Wight kelimelerini önerir. Bane, elf kavramının mitolojiler ve folklorda ne şekilde kullanıldığına dair ayrıntılı bir çalı̧̧ma sunar. Tanımında elf kelimesini kullanan Bane, onun, içerisinde cücelerin ve trollerin bulunduğu peri halkının geniş bir kolunu kapsayan ve peri kelimesi ile yer değiştirebilecek özellikte olan genetik bir kelime olduğunu savunur. Bane, elf kavramının İngiltere'de evcil ve kırsal elfler olmak üzere iki farklı sınıfa ayrıldığını belirtir. Evcil elfler, insanlar ile birlikte onların çiftliklerinde ve evlerinde yaşayan ev perisi olarak görülürken, kırsal elfler mağaralarda, tarlalarda, dağlarda ve kırsalda yaşar. İskandinav mitlerinde elfler, Light Elves (Işı1k Elfleri) ve Dark Elves (Kara Elfler) olarak, tıpk1 İngiliz folklorunda olduğu gibi iki sınıfa ayrılır. Cermen ve İskandinav folklorlarında elfler, Huldrafolk olarak da adlandırılır. Önceleri toprağa doğurganlık getiren ölülerin ruhları olduğuna inanılırdı. Sonraları ise, küçük, insansı varlıklar olarak gelişim gösterir ve güzel olanlar Işık Elfleri olarak kabul görmeye başlar. Çirkin olanlar ise kara ya da Kara Elfler olarak ifade edilir. İskoçya perileri insan boyutundadır ve Elves olarak adlandırılır. Yaşadıkları yerin adı Elfame'dir. Galler folklorunda ise elfler, Ellyllon olarak adlandırılır. Ellyllon'lar cehennem mahkûmu olan ve cennete girmelerine izin verilmeyen, antik dönemin ruhlarıdır ve daha yüksek bir konuma erişmelerine izin verilene dek, kıyamet gününe kadar insanlar arasında yeryüzünde 
dolaşma ile cezalandırılmışlardır. Afrika'daki elfler ise mevsimlik perilerdir ve doğa perileri ile oldukça benzerlik gösterirler (Bkz. Bane, 2015: 117).

Richard Cleasby ve Gudbrand Vigfusson, An Icelandic-English Dictionary (İzlandacaIngilizce Sözlüğ̈̈) adlı çalışmalarında, Álfr kelimesine gönderme yapar. İngilizce'de elf ve elves kelimelerinin kullanımına dikkat çeken Cleasby ve Vigfusson, Sheakespeare'in sonelerinde peri olarak kullanıldığını örnekler. Almanca'daki Alb ve Elfen kelimelerine gönderme yapar. Goethe'nin ünlü şiiri Erlkönig'in adının Danca'daki Ellekonge ve Elverkonge (Elf Kral) kelimelerinden türetildiğini ifade eder. İskandinav mitlerinin en eski kaynağı olan Edda'daki mitsel kullanımını dile getiren Cleasby ve Vigfusson, Ljósálfar (Işsık Elfleri) ve Dökálfar (Kara Elfler) kullanımından bahseder. Elflerin yurdunun Edda'da Álfheimar (Elf Yurdu) olarak geçtiğini beliritir (Cleasby and Vigfusson, 1874: 42).

Sir Walter Scott, İngilizce'deki elf kavramının prototipinin İskandinav mitlerinde yer alan duergar (cücelere verilen isim) kavramında aranmasını önerir. İzlanda Saga'larının en erken dönemlerinde ve Edda'da, kayalık dağlarda yaşayan ve bazı açılardan insan doğasına yakın, kuzey ulusuna bağlı bir cüce 1rkına olan inanıştan bahseder (Mallord and Turner, 2007: 255). Bu bağlamda, İskandinav mitlerinde elfler, cüceler, nornlar, cadılar ve valkyrieler ile birlikte Tanrılar sınıfının altında yer alır (Page, 2009, s. 12) ve yeryüzünün derinliklerinde yaşayan Kara Elfler ile Alfheim denen bölgede yaşayan Işsk Elfleri olmak üzere iki tür elf bulunur (Page, 2009: 110).

Tolkien ise, elf sözcügünün türetilmesini bir İngiliz düşünüre dayandırır. Tolkien'e göre; İngiliz düşünür, ylfe, bilindik haliyle elfler sözcügünü, Kabil'in Adem'in soyundan gelmesinden türetmiştir (Tolkien, 1999: 25).

Elf kavramı, birçok ülkenin mitolojisinde ve folklorunda yer alsa da bugünkü popülaritesini İngiliz yazar, filolog ve Anglo-Saxon Dili ve Edebiyatı profesörü John Ronald Reuel Tolkien'in (J.R.R. Tolkien) eserlerine borçludur. 1937 yılında yayımladığ 1 The Hobbit adlı eseri ile elf ırkının da yaşadığı Orta Dünya'yı oluşturmaya başlayan Tolkien, The Hobbit' in devamı olan 1954 yılında yayımladığı The Lord of the Rings (Yüzüklerin Efendisi) trilojisi ile "modern fantezi türünün oluşmasında büyük bir katkıda bulunur" (Senior, 1995: 62) ve geniş ölçüde bir okur kitlesine ulaşır. 1977 yayınlı Silmarillion ve 1910'un sonralarında yazmaya başladığı ölümünden sonra oğlu Christopher Tolkien'in editörlüğünde 2007 yılında yayımlanan The Children of Húrin (Húrin'in Çocukları) eserleri ile oluşturduğu Orta Dünyası'nı okurun hizmetine sunar. Orta Dünya'nın doğası ve canlıları kadimdir; geçmişleri dünyanın yaratılışına kadar uzanmaktadır. İlk doğanlar olarak da adlandırılan elf halkı ölümsüzdür; ancak başka birisi tarafından öldürülebilirler. Cücelerin ve insanların ömürleri ise yüzlerce yıl sürebilmektedir. Tolkien'in kadim doğa anlayışını en iyi ağaçlar ve ormanlar yansıtmaktadır (Eryılmaz, 2018: 103). Tolkien'in yarattığı Orta Dünya'da elf 1rk1 önemli bir yere sahiptir. İnsanların aksine elfler, ölümsüz bir ırk olarak tasvir edilir. Bir elf öldüğünde, ölümsüzlük ülkesinde yeniden doğar. Elfler, vücut olarak harika bir yapıya sahiptir. Ortalama bir insandan daha büyük, daha hızlı ve daha çeviktir (Warmer, 2012). Ayrıca Tolkien, elf ya da peri olsun mini boyutlardaki yaratıkların asıl olarak İngiltere'deki fantazinin gelişkin bir ürünü olduğundan bahseder (Tolkien, 1999: 15).

Ludwig Tieck'in Elfler adlı masalını, elf kavramı açısından önemli kılan şey yazıldığı tarih ve dönemdir. Elfler, Tieck'in birçok romantik yazarın ele aldığı Kunstmärchen (sanatlı, yazarı belli olan masal) türü ile yazdığı Phantasus eserinin içerisinde yer alır. Masalın adını oluşturan ve masalın kurgusunda da önemli yere sahip olan elf kavramından, Tieck tarafından Tolkien'den yaklaşık yüz y1l önce -Hurin'in Çocukları eserinin 1910'un sonlarında yazılmaya başlandığ1 düşünülürse- 1812 yılında bahsedilmiştir. William Shakespeare'in sonelerinde elf kavramına rastlanılsa da, Shakespeare yan karakter olarak kurguladığı elf figürünü, peri anlamında kullanır. Bir tür olarak elf kavramından bahsedilmesi, belki de ilk kez Ludwig Tieck tarafından gerçekleşmiştir. 
Elfler masalında, Marie tesadüfen gittiği Elf Diyarında, parıldayan ve "aralarında en sevecen ve en güzel olan" (Tieck, 2004: 14) Zerina ile yakınlaşır. Bu yakınlaşmayı sezen 1şıldayan cübbesi içerisinde bir kadın onlara doğru yaklaşır ve "küçük kız burada sadece klsa bir süre kalabilir; ayrıca bunun için önce benden izin alman gerekirdi" (Tieck, 2004: 14) cümlesini sarf eder. Bu sözler elflerin leydisine aittir.

Kısıtlı bir süre için leydiden izin alan Zerina ve Marie göl kıyısında gezerken, Marie gölün içerisinde çok sayıda çocuk olduğunu görür ve bu durum "birdenbire, bütün kanallardan ve gölün dört bir yanından yüzerek çocuklar gelmeye başladl; bazıları melisa ve nilüferlerden taçlar takmıştı. Bazılarının başında kırmızı mercan dalları vardı, bazıları da boynuz şeklindeki deniz kabuklarına üflüyordu; neşeli sesler karanlık kıyılarda yankılandı. Aralarında güzeller güzeli kadınlar yüzmekteydi. Çocuklar kadınlara dokunabilmek için birbiriyle yarışıor, kadınların omuzlarına ve boyunlarına öpücükler konduruyordu" (Tieck, 2014: 23) cümleleri ile dillendirilir.

Masaldaki kilit nokta Marie'nin Zerina'ya kim olduklarını sorduğunda yaşanır. Zerina'nın "Biz Elfler'iz” (Tieck, 2004: 28) cevabı ile Marie, olağanüstü bir dünyada gezmekte olduğunun bilincine varır.

Zerina'nın, kimliklerini Marie'ye itiraf ettikten sonra sarf ettiği “duyduğum kadarıyla Dünyada insanlar bizden bahsediyorlarmış" (Tieck, 2004: 28) cümlesi, Tolkien' in "elflerin asıl olarak ilgilendikleri biz değiliz, bizim de asıl ilgi alanımız onlar değil. Kaderlerimiz ayrılmıştır ve yollarımız da çok ender olarak kesişir. Periler Diyarı'nın sinırlarında bile onlarla ancak yolların şans eseri kesişmelerinde karşılaşırız” (Tolkien, 1999: 21) ifadesine karşılık gelir.

\subsection{Sihirli Tohum}

Zerina, artık arkadaşı olan Marie'ye etrafı gezdirirken bir ara saraya gider. Geri döndügünde elinde altından yapılma bir kutu vardır. "Kutunun içinde parıldayan tozlara benzeyen tohumlar vardı. Küçük elini önce kutuya daldırdl, sonra da çıkarıp havaya kaldırdı ve tohumları yeşil toprăga serpiştirdi. $O$ anda çimenler sanki dalgalanır gibi kımıldand, ve birkaç dakika sonra topraktan parıl parıl parlayan gül ağaçları fişkırmaya başladı. Ağaçlar hızla büyüdü; ve hemen gonca verdi. Etrafa çok tatlı bir parfüm kokusu yayıldl. Mary de tozdan bir parça alıp serpiştirmişti. Etrafinda beyaz leylakların ve en alacalı karanfillerin açtığını gördü. Sonra Zerina'nın bir işaretiyle bütün çiçekler yok oldu ve yerlerinde yenileri açtı" (Tieck, 2004: 16) alıntıs1, kutunun sihirli olduğuna vurgu yapar. Sihirli nesneler, peri masallarında sıklıkla yer alır. Zerina'nın saraydan getirdiği tohum, toprağa atıldığı anda tarif edilemez güzellikteki güllerin, leylakların, karanfillerin açmasını sağlar. Üstelik Zerina, bir işareti ile bütün çiçeklerin yok olmasını sağlar. Yok olan güller yeniden açıp, hayat bulur.

$\mathrm{Bu}$ anlatıma benzer bir durum da İngiliz anonim peri masalı özelliği taşıyan Jack and The Beanstalk'ta (Jack ve Fasulye Sirığı) yaşanır. Yazarı ve ne zaman anlatılmaya başlandığı tam olarak bilinemeyen ve bugün benzer versiyonlarının yazıldığı masal, ilk olarak 1800'lü yılların başlarında yayımlanır. Bunların en bilindiği, Benjamin Tabart'ın Jack ve dev arasındaki maceraları yeniden yorumladığ 1807 yılında yayımlanan The History of Jack and Bean-Stalk (Jack ve Fasulye Sirı̆̆ının Tarihi) adlı masalıdır (Hoena, 2016: 107). Masal, genel hatları ile çok fakir olan bir anne-oğul üzerine yoğunlaşır. Jack, bir gün tek varlıkları olan ineğini gezdirirken, yaşlı bir adam ile karşılaşır. Adam elinde sihirli fasulye taneleri olduğunu, fakat karşıllğında ineği ona vermesini ister. Jack, bunu kabul eder ve tohumları toprağa eker. Fasulye sırığı birden yükselip göğe kadar çıkmaya başlar. Jack, fasulye sırığı ile birlikte çok yüksek bir ülkeye gider, orada başına türlü maceralar gelir ve amansız devi yenip, ülkesine döner ve fasulyenin bereketi ile birlikte annesi ile rahat bir yaşam sürer.

Bir tohumun sihirli olması ve çok kısa sürede bu denli etki göstermesi, olağanüstü ve mucizevi bir durumdur. Bu durum ancak bir peri masalı düzleminde görülebilir. Benzer şekilde Elfler masalında da Zerina yere iki çam tohumu atar ve Marie'nin "yukarı doğru hareket 
ettiklerini hissetti; ağaçlar altlarında büyük bir hızla yükseldi, yüksek çamlar bir öne bir arkaya dalgalanırken birbirine sıkı sıkı sarılan iki çocuk da alaca karanlığın kızıl bulutları içinde sallandı" (Tieck, 2004: 16) şeklindeki anlatımında yer alan iki çam ağacı, Jack'in fasulye sırığı gibi yerden yükselmeye başlar. Marie korkunca bunu fark eden bir çocuk bir şarkı söyler ve ağaç yeniden aşağı iner. Küçük çocuğun söylediği şarkı, ağacın yeniden aşağıya inmesi için sihirli bir komut görevini görür.

\subsection{Elf Sarayı}

Gerek peri masalları gerek ise diğer masal türlerinde olsun, saray, masallar açısından önemli bir vurgudur. "Uzak Diyarlarda bir sarayda bir prens/prenses yaşarmış" şeklinde başlayan çok sayıda peri masalı ile karşılaşmak mümkündür. Saray, bazen hapsedilen bir prensesin, bazen sihirli olayların, bazen de Grimm masallarından olan Aschenputtel'deki (Külkedisi) gibi bir prenses ile prensin tanışma mekânıdır.

Elfler masalında, Elf Diyarı'nda yer alan saray, kendi içinde çok katmanlı, muazzam ölçüde büyük ve görkemli bir güzelliğe sahip olarak resmedilir. Elf Sarayı masalda: "Sarayın pirinç kapısından içeri girdiler. Burada çok sayıda sarışın güzel kadın daire şeklinde bir salonda oturmuş en güzel meyveleri yiyip muhteşem görünmez müziği dinlemekteydi. Kubbe tavanda rengârenk çiçek ve ağaç resimleri vardı. Bu çiçek ve ağaçların arasında oyun oynayan küçük çocuklar en zarif duruşlarlyla resmedilmişti. Ve görünmez müziğin tonuna göre de bu resimler renk değiştiriyor, göz alıcı bir şekilde parlyyordu; önce parlak maviler ve yeşiller etrafa ışı saçmaktaydı ve şimdi de bu tonlar parlaklığını yitirerek soldu ve mor tonları canlandl, altın sarısı alev aldı. Sonra da çiçek bahçelerindeki çıplak çocuklar canlanmış gibi göründü. Sanki yakut rengi dudaklarl nefes alıp veriyordu; öyle ki ara sira küçük beyaz dişlerinin parladığını ve gök mavisi gözlerinin ışıldadığını görmek mümkündü” (Teick, 2004: 18) şeklinde tasvir edilir. Elf Sarayı, içerisinde elfleri, perileri, cüceleri barındıran bir yapıya sahiptir. Peri masalları ya da mitler olsun; elfler, ekseriyetle periler ve cüceler ile ilişkilendirilir ve yakın ırklara sahip olduğunun altı çizilir. O halde hepsi, Elf Sarayı'nda akrabaymış gibi bir arada uyum içerisinde yaşıyor demek yanlış olmaz. Elf Sarayı'nda herkesin bir görevi vardır. Elfler sarayın yerli halkıdır. Cüceler, yer altındaki mücevher odasından sorumludur. Odada yer alan mücevherleri madenlerine göre sınıflandırır. Ateş Oda sakinleri, ateş sularını yar altına yayarak çiçek ve meyvelerin çabuk büyümesini sağlar. Kuşkanatlı saray bekçileri, yabancılara karşı, sarayı korur. Saray öyle huzurludur ki herkes görevini canla başla yerine getirir.

Elf Sarayı'nı değerli kılan diğer bir unsur, yer altı odasında bulunan mücevher odasıdır: "Pirinç bir merdivenden bir yer altı odasına indiler. Burası altın ve gümüş doluydu. Aralarındaki değerli taşlar renk renk parlamaktaydı. Altın işlenerek çok farklı şekillere sokulmuştu ve renk alıyordu" (Tieck, 2004: 18-20) cümlelerinden elf halkının zengin ve bolluk içerisinde olduğunu söylemek yerindedir. Mücevher odasında yalnızca değerli eşyalar yoktur, aynı zamanda Marie'nin ülkesine geri dönmesini sağlayan sihirli yüzük, Elfriede'nin boynundaki kolye, Zerina'nın getirdiği sihirli tohum gibi sihirli nesneler de bulunur.

\subsection{Cüceler}

Cüceler, tıpkı peri ve elfler gibi peri masallarında yer alan figürlerdir. Tolkien, her ne kadar Orta Dünya evrenini oluşturduğu yapıtlarında elfler ve cüceler arasında geçimsizlik ve husumet kurgulasa da Ludwig Tieck, Elfler masalında elfleri ve cüceleri bir uyum içerisinde kurgular. Hatta elfler, cücelere Elf Sarayı'nın hazine bölümünü teslim edecek kadar güvenirler. Bu güven; "pek çok küçük cüce bu yı̆̆ındaki değerli parçaları türlerine göre ayırıp fiçılara doldurmakla meşguldü; kambur, çarpık bacaklı ve uzun kırmızı burunlu diğer cüceler yere kadar eğilmiş, sırtlarındaki dolu keseleri yavaş yavaş taşımaktaydı" (Tieck, 2004: 20) cümlesi ile özetlenmiştir.

Tieck, masalında peri masalları figürlerinden olan cüceleri sempatik bir tavırla selamlar. İki cücenin telaş içerisinde çalışırken düştüğünü ve Marie'nin onların bu haline güldüğünü 
okuyan okur, kafasında iki sevimli cüce tahayyül eder. Bu tahayyül etme durumu, Tieck'in cüce figürünü karikatürize etmesi anlamına gelmemelidir. Zira Maden prensi cüceyi selamlayan Zerina'nın yaşlı prense saygı göstermesi, cücelerin Elf Diyarı içerisinde ciddiye alınan figürler olduğunu imler. "Aralarında yaşlı buruş buruş küçük bir adam oturmaktaydı. Zerina bu adamı reverans yaparak selamladı. Adam ciddi bir ifadeyle hafifçe başını eğerek Zerina'ya teşekkür etti. Elinde bir hükümdar asası alnında da bir taç vardı. Diğer cüceler onu efendileri olarak görüyor ve emirlerine uyuyorlard"” (Tieck, 2004: 20) cümlesi, cücelere duyulan saygıyı gözler önüne sermektedir.

\subsection{Ateşle Dans Edenler}

Marie, sarayı gezerken kendini bir anda ateş gibi parıldayan bir salonda bulur. Ateşten oda, gerçekte olamayacak kadar gizemlidir: "Alev rengi duvar halısı duvarları mor bir ateşle kaplıyordu; gözleri buna biraz alıştı̆̆ında yabancı, şaşkınlık içinde halıdaki insan suretlerinin neşeyle dans eder gibi bir yukarı bir aşağı hareket ettiğini gördü; bedenleri o kadar güzel, o kadar estetikti ki başka hiçbir şey böylesine zarif görünemezdi. Sanki kırmızı kristaldendi bu bedenler, sanki içlerinde akan kan görünür olmuştu” (Tieck, 2004: 23). Alıntıda yer alan tasvirler, odanın büyülü güçler tarafından ele geçirildiği kanısını uyandırır. Nitekim bir duvar halısında yer alan bir figürün hareket etmesi olağan, aynı zamanda şahit olan üzerinde büyük korku uyandıracak ve ancak peri masallarında olabilecek bir olaydır.

Marie büyük bir merak ile onların kim olduğunu sorduğunda Zerina, "onlar da Ateşle yaşıyorlar. Ĕger Ateş'ten çıkarlarsa güçlerini kaybeder ve solarlar. Baksana, orada ne kadar da mutlular, nasıl da gülüp eğleniyorlar. Burada yaşayanlar ateşten suları toprağın altından her yere dağitırlar. Böylece çiçekler, meyveler çabucak gelişir. Bahçelerimizin güzelliği ve bereketi için bu ateşten yaratıklar durmadan çalışırlar ve bundan da oldukça memnunlar" (Tieck, 2004: 24) cevabını verir.

\subsection{Elf Diyarı Bekçileri}

Zerina, Marie'ye Elf Diyarı bekçilerini göstermek istediğini söyler. İki küçük çocuk tepeye ulaştıklarında, "tepede çok sayıda tuhaf şekil duruyordu: yüzleri solgun ve tozlu gibiydi, beyaz baykuşlara benzeyen biçimsiz başları kaba yünden pelerinle örtülmüsstü. Başlarının üzerinde tuhaf deriden şemsiyeler tutuyorlar ve kendilerini sürekli olarak büyük yarasa kanatlartyla yelliyorlardı" (Tieck, 2004: 26) şeklinde bir sahne ile karşılaşırlar. Marie, gördüğü bu tuhaflık karşısında merakına yenik düşer ve Zerina'ya bu tuhaf görünüşlü yaratıkların kim olduğunu sorar. Zerina, iyi kalpli, güvenilir bekçilerimiz olarak tanıttığı yaratıkların, Elf Sarayı'nı korumak adına nasıl uğraş verdiklerinden şu şekilde bahseder: “Burada durup yelpazelerini sallarlar. Böylece bize yaklaşmaya kalklşan herkes soğuk bir endişe hisseder, anlaşılmaz ve açılanamaz bir korkuya kapılır. Kendilerini örtüyorlar çünkü bunu yapmazlarsa oradaki soğuya ve yağmura dayanamazlar. Ama kar, rüzgâr ya da soğuk hava asla aşağl inip bize kadar gelmez. Burada sonsuz bir bahar ve yaz havası hüküm sürer: eğer tepedeki bu zavallı adamlar sik sik nöbet değiştirmeselerdi kesinlikle ölürlerdi” (Tieck, 2004: 26). Bekçiler, tehlikeli olarak gördükleri kişiler üzerinde tekinsiz bir korku hissi uyandırır. Onlar yağmurlu ve karlı tepenin bekçileridir.

\subsection{Zümrüd-ü Anka (Simurg)}

Zümrüd-ü Anka, Pers mitolojisi kaynaklı mitolojik bir motiftir. Pers mitolojisinde Simurg olarak geçen efsanevi kuş motifi, zamanla Doğu mitolojisi başta olmak üzere birçok ülkenin mitlerinde yer almaya başlar. Arap mitolojisinde Anka, Türk mitolojisinde ise yeşil olduğuna inanıldığı için Zümrüdü Anka ya da Tuğrul Kuşu gibi kullanımlara karş1lık gelir. Macar mitolojisinde de önemli bir yere sahip olan efsanevi kuş motifinde "otuz kuşun rengi, büyüklüğ̈̈ ve özellikleri olduğuna inanılmaktadır” (Özdăg, 2017: 199).

Deniz Gezgin, Hayvan Mitosları adlı çalışmasında, Anka kuşunun düşsel dünyada yaratılmasına ve somut bir varlık olmamasına karşın insanın manevi dünyasında büyük ve 
uhrevi anlamlar ifade ettiğinden bahseder. Gezgin, kendi küllerinden var olan Anka kuşunun, dünyada sadece bir tane olduğunun altını çizer (Gezgin, 2007: 20). Zümrüd-ü Anka kuşunun, masallarda mekân olarak sıklıkla geçen efsanevi Kaf Dağı'nda yaşanıldığına inanılır. Ludwig Tieck, masalında efsanevi kuş Zümrüdü Anka'yı Elf Kral'ının geleceğini müjdeleyen habercisi konumuna getirir. Zümrüdü Anka kuşu masalda şu şeklide tasvir edilmiştir: "Mor ve yeşil tüylerinin arasında yol yol altın sarısı parıltılar vardl; başında dikili duran tüy demetiyse bir tacı andırıyor, dalgalandıkça mücevherler gibi ışık saçıyordu. Gagası kırmızı, bacakları parlak maviydi. Hareket ederken bu renkler birbirine karışıyor, göz alıcı ışık oyunları yapıyordu. Bir kartal kadar büyük olan Masal Kuşu şimdi parıldayan gagasını açtı ve yükselip açılan göğsünden en tatlı melodiler döküldü. Ötüşü kara sevdalı bir bülbülünkinden kat kat güzeldi (Tieck, 2004: 28-29).

Ludwig Tieck, peri masalı formunda kurguladığı masalında, Zümrüd-ü Anka kuşunu tasvir ederken, okura Arap mitolojisinden esinlendiği konusunda ipuçları verir. Elfler adlı masalda kuş ile ilgili “Arabistan'ın ücra bir yerinde, bir ağaçta yaşar. Dünyada o ăgaca benzeyen başka bir ă̆aç yoktur; tıpk ikinci bir Anka olmadığı gibi. Yaşlandığını hissedince, melisa ve güzel kokulu otlardan bir yığın yapar, onu ateşe verir ve üzerinde şarkı söyleyerek ölür ve sonra güzel kokulu küllerde yeniden hayat bulur ve göğe yükselir, güzelliğinden hiçbir şey yitirmemiştir" (Tieck, 2004: 29-30) şeklindeki betimlemeler ve eserde Anka ifadesinin geçmesi bu kanıyı kuvvetlendirir.

\subsection{Elf Kral}

Zerina, Elf leydinin Marie'nin kalması konusunda sert bir tavır takınmasını elflerin insanoğluna karşı geliştirdiği mesafeye ve Elf Kral'ın ziyarete gelecek olmasına bağlar. Marie'nin leydinin uzun süre kalamayacağını bildirmesinin ardından yaşadığı üzüntüye karşılık, Zerina'nın sarf ettiği "Kral halkını yirmi yıl boyunca, belki de daha fazla, burada tutacak; buradaki iyilik ve bereket uzak topraklara kadar yayllacak; bütün sular ve dereler daha verimli bir hale gelecek, bütün tarla ve bahçeler daha da zenginleşecek, bağlar daha cömert, çayırlar daha bereketli, ağaçlar daha yeşil olacak, hava daha llı esecek, dolu ürüne zarar vermeyecek, seller tehlike yaratmayacak" (Tieck, 2004: 30) şeklindeki sözleri, Elf Diyarı sakinlerinin, krallarını büyük bir merak, heves ve umutla beklediklerini açığa çıkarır.

Leydinin Marie hakkındaki çekinceleri onu haklı çıkarır. Nitekim Marie yetişkin olup, anne olduğunda kızı Elfriede'nin Zerina ile arasındaki kuvvetli bağı algılayamaz ve kocasına her şeyi anlatır. Bu Zerina ve Elf Diyarı sakinleri için sonun başlangıcıdır. Elf Diyarı sakinlerinin uyması gereken en önemli kural, kimliklerini gizlemeleridir ve Zerina büyük bir hata yapmıştır ve hatasının cezasını çeker. Marie'nin hiddetli kocası Andres'i elflerin onların velinimeti oldukları konusundaki ikna çabaları sırasında, Andres kızının sıklıkla gittiği arka bahçeyi gören delikten kızına bakmak için içeriye göz gezdirir. "Onunla oynayan parıltılı Elf' $i$ görünce şaşırıp kaldl. Ne diyeceğini bilemedi ve heyecandan bir çı̆̆lık kopardı" (Tieck, 2004: 43) şeklideki cümle, Andres'in deneyimlediği bu olağanüstü görüntü karşısında yaşadığı şokun derecesini gösterir. Zerina için bu durum son derece endişe vericidir. Marie'den sonra başka bir insan tarafından fark edilir. Bu karşılaşma durumu Zerina cephesinde şu şekilde betimlenir: "Aynı anda yüzü soldu, dehşet içinde deli gibi titremeye başladı. Bu defa bakışları dostane değil kızgındı ama tehditkâr bir işaret ya da davranışta bulunmadı. Elfrida'ya dönüp dedi ki. "Buna engel olamazsın, canım benim; bunlar asla akıllanmayacaklar, sandıklar gibi sağduyulu olamayacaklar." Küçük Elfrida'y aceleyle ve sinirli bir şekilde kucakladı ve sonra bir kuzgun şeklini alarak kaba ötüşlerle bahçenin üzerinden Köknarlar'a doğru uçtu”" (Tieck, 2004: 4344). Bu Elfriede ile Zerina'nın vedalaşması olur ve iki dost birbirini bir daha görmemek üzere ayrılır. Tieck, kuzgun motifini kıyametin habercisi anlamı ile kullanır. Olayın yaşandığı gece, derenin diğer tarafından gürültüler, inlemeler duyulur. Kral, Elf Diyarı sakinlerini başka bir diyara götürür. $\mathrm{O}$ gece elfler, periler ve cüceler halk arasına karışır ve deniz yoluyla kaçar. Denizci o geceyi anlatırken Elf, Kral'1 "sonra tekneden çok gösterişli bir yolcu indi. Bu, küçük beyaz bir ata binmiş yaşlı bir adamdı ve herkes adamın çevresine toplandl. Atın sadece başını 
görebildim çünkü geri kalanı pahalı parlak kumaşlar ve süslü koşum takımlarıyla örtülüydü: adamın alnında bir taç vardı, öylesine parlaktı $\mathrm{ki}$, adam yaklaştı̆̆ında güneş sanki orada doğuyor ve şafağın klzıllı̆̆ gözlerimi alıyor zannettim" (Tieck, 2004: 47) şeklinde betimler. Göç gecesinden sonra derenin karşı tarafı gizemli görünüşünü yitirir. Artık tamamıyla boş ve kimsesiz bir görüntüye sahiptir. Elf Diyarı sakinleri çok sevdikleri Elf Sarayı'ndan çok uzakta, tıpkı Zümrüd-ü Anka'nın yeniden dirilmesi gibi başka bir diyarda yeniden hayat bulurlar.

\subsection{Elfriede}

Marie, çocukken yaşadığı olağanüstü deneyimin anısı olarak kızının adını Elfriede koyar. Elfriede, normal bir çocuk olmaktan çok uzakta sanki büyülü bir varlık gibidir: "Klsa süre sonra küçük Elfrida tuhaf tanrı vergisi yetenekler sergilemeye başlamıştı. Çok erken bir yaşta yürüdü, daha bir yaşını doldurmadan kusursuz bir şekilde konuşabiliyordu ve birkaç yıl sonra o kadar zeki, akıllı ve güzel bir kiz oldu ki insanlar ona hayranlı duyup büyük bir saygı gösteriyordu; annesi kızının Köknarlar ardındaki yerde yaşayan küçük ışıl ışıl varlıklara benzediği düşüncesinden kendini alamıyordu” (Tieck, 2004: 36). Alıntıdan da anlaşılacağ üzere, sanki Marie'nin tesadüfen gittiği Elf Diyarının o büyülü ortamı, küçük kızın tüm genlerine işlemiş gibidir. Marie, yedi yıl sonra geri döndüğünde garip ölçüde güzelleşmiştir. Büyümenin getirdiği başka sorumluluklar ile yaşadığı deneyimi unutan Marie, kızı Elfriede'nin olağanüstülüğünü her fark edişinde, Elf Diyarı'ndaki iyi kalpli dostunu anar. Oysa Zerina, ona görünmeden küçük kızının tek dostu olmuştur bile. Bu bağ öyle kuvvetlidir ki, Marie'nin Zerina'nın varlığını kocasına anlattığı hatalı davranışından sonra, Elfriede, dostu Zerina'yı bir daha görmeyecek olması düşüncesi ile solup ölür. "Solarak ölmek", periler ve elfler için kullanılan bir tabirdir. Elfriede'de tıpkı küçük bir perinin başına gelebilecek bir durumu yaşar ve kederinden solar.

\section{Sonuç ve Öneriler}

Gerçek dünyanın katılığının tam ortasına büyülü olanın kolajlanması, gerçekliğin tüm o sorumluluklarından, travmalarından uzaklaşmayı ve bir anlamda ruhsal olarak katarsis yaşamayı beraberinde getirir. Ruhsal olarak katarsis yaşama dürtüsü, Romantik Dönem'in karakteristiğidir. $\mathrm{Bu}$ bağlamda, peri masalının bir yazın türü olarak ele alınması Romantik Dönem ile birlikte olur. Özellikle Alman yazınındaki erken Romantik Dönemi yazarları, Märchen olarak adlandırdıkları ve peri masalı anlamında kullanılan bir yazın türü geliştirir. Novalis'in mavi çiçek izleği, bu tür için en güzel örneklerden biridir.

Alman erken Romantik Dönemi yazarlarından olan Johann Ludwig Tieck, -çalışmada daha çok kullanıldığı için yalnızca Ludwig Tieck olarak ele alınmıştır- yazın tarzı ile dönemin adından söz ettiren yazarlarından biri haline gelir. 1797 yılında yayımladığı Der blonde Eckbert (Sarışın Eckbert) ile o zamana değin alışılagelmiş yazın tarzının tüm ezberlerini bozar. Tieck, Kunstmärchen (sanatlı masal) tarzında -ki Kunstmärchen tarzını ilk kullanan yazarın Tieck olduğu konusunda birçok edebiyat kuramcısı hemfikirdir- yazdığı ilk eseri olan Der blonde Eckbert'de (Sarışın Eckbert), doğaüstüyü, cinleri, perileri ustaca kaleme alır. Karanlık ve kasvetli bir ormanda kahramanları türlü maceralar bekler. Tieck, Kunstmärchen tarzında kaleme aldığı 1812 yayın tarihli Phantasus adlı serisinde de peri masalı türünde eserler kurgular. İlk cildinde yer alan Elfler adlı masalında, ormanın karanlık ve kasvetli bir bölgesini mekân olarak seçer. İçeriden bir cennet güzelliğine sahip olan mekân, dışarıdan oldukça tekinsiz bir izlenim verir. Oysa içerisinde perilerin, elflerin ve cücelerin yaşadığı doğaüstü ve huzurlu bir ortamdır. Tieck Elfler adlı masalında, peri masallarında sıklıkla yer alan perilere, elflere, cücelere, ruhani varlıklara yer verir. Sihrin hâkim olduğu bir anlatım ile Tieck, okuruna doğaüstü bir deneyim yaşatır.

Küçük elf Zerina'nın kimliğinin ortaya çıkmasından sonra ortadan kaybolması, Elfriede için sonun başlangıcı olur. Küçük kız üzüntüsünden solar ve ölür. Onu takiben annesi Marie'de yaşama veda eder. Ölüm ve dolayısı ile mutsuz son, mutlu sonla biten diğer peri masallarından farklı olarak, Tieck'in eserlerinde genellikle tasarladığ 1 bir durumdur. Bu durum, masallarda 
iyiliğin kazanıp kötülüğün kaybetmesine olan inanışı alaşağı eder. Peri masalları, kültürel aktarımlar ile bireylerde kolektif bilinçdışı oluşturmak bağlamında önem arz eder. Nesiller boyunca kodlanan bu olağanüstü deneyimler, bireyin bilinçdışı katmanında her zaman özel bir yere sahiptir. Gerçekliğin baskısı altında ezilen birey, doğaüstü evrende katarsis yaşar. Kötülerin cezalandırıldığı, iyilerin ise mükâfatlandırıldığ 1 bir anlatım, okurun psikolojik olarak rahatlamasına neden olur. Gerçek yaşamda edinemediği bu deneyimi, peri masalı vasıtası ile kazanır. Küçük elf Zerina'nın çok sevdiği arkadaşı Marie'nin ihanetine uğraması, dostu Elfriede'yi bir daha hiç görmeyecek olması, Elfriede ve akabinde Marie'nin trajik ölümü, peri masalının okur üzerinde katarsis oluşturma özelliğine ters düşer.

Ludwig Tieck'in Elfler adlı masalını, peri masalı türü ekseninde incelemeye değer kılan unsur ise, elf kavramının ilk kez yazılı ve edebi tarzdaki bir metinde yer almasıdır. Tolkien, kendi Orta Dünyası'nı yaratırken İskandinav mitolojisinden ve Ludwig Tieck'in elf tasvirinden etkilendiğini dillendirir. İskandinav mitolojisinde genişçe yer bulan elf kavramının Tolkien'in Yüzüklerin Efendisi trilojisi ile popülarite kazanması, beraberinde kavramın edebi olarak ilk kez Tolkien tarafından kullandığı yanılgısını getirir. Tolkien'in yarattığı Orta Dünya, kuşkusuz yazın dünyası için yeni bir soluktur. Aynı zamanda çalışma, okuru bu yanılgıdan kurtarmak, Alman Romantik Dönemi yazarı Ludwig Tieck'in kısa ölçekli masalı Elfler'den haberdar etmek ve bu bağlamda sonraki çalışmalara 1şı tutmak açısından önem arz etmektedir.

\section{Kaynakça}

Asutay, H. (2014). Çocuk ve Gençlik Yazınında Fantastik Kavramı, Türk Dili-Dil ve Edebiyat Dergisi, CVII (756): 642-652.

Aytaç, G. (1983). Yeni Alman Edebiyatı Tarihi, Ankara: Gündoğan Yayınları.

Bane, T. (2015). Encyclopedia of Beasts and Monsters in Myth, Legend and Folklore, Jefferson, North Carolina: McFarland\&Company, Inc. Publisher.

Bettelheim B. (1999). Masal-Mit (İyimserlik-Kötümserlik, İçinde: Büyünün Yararlart- Peri Masallarının Anlam ve Önemi, (Çev: Sevinç Kabakçığlu), Kuram Dergisi, Kitap:6, İçinde: Sarı, A. Ve A. Ercan, C. (2008). Masalların Psikanalizi, Erzurum: Salkımsöğüt Yayınları.

Bottingheimer, R. B. (2009). Fairy Tales: A New History, Albany: State University of New York Press.

Cleasby, R. and Vigfusson, G. (1874). An Icelandic-English Dictionary, Oxford: The Clarenden Press.

Doğan, E. (2018). Türk Sinemasında Masal Uyarlamaları ve Vladimir Propp'un Halk Masalları İşlevlerinin Pamuk Prenses Ve Yedi Cüceler (1970) Filminde Çözümlenmesi, Turkish Studies, 13(23): 53-63.

Duman, N. (2018). Peri Masallarının Orjini, Asya Studies-Academic Social Studies/Akademik Sosyal Araştırmalar, 5, Autumn: 67-72.

Eryılmaz, Ç. (2018). Tolkien'in Yüzüklerin Efendisi Eserinin Çevreci Analizi: Y1kıcı Endüstriye Karş1 Kır Yaşamı, MCBÜ Sosyal Bilimler Dergisi, 16(1/2): 93-118.

Gebhardt, A. (1997). Ludwig Tieck: Leben und Gesamtwerk des "Königs der Romantik", Marburg: Tectum Verlag.

Gezgin; D. (2007). Hayvan Mitoslarl, İstanbul: Sel Yayıncıl1k.

Hoena, B.A. (2016). Jack and the Beanstalk: An Interactive Fairy Tale Adventure, Canada: Capstone.

Jones, S. S. (2002). The Fairy Tale, New York: Routledge. 
Mallord, J. and Turner, W. (2007). The Poetical Works of Sir Walter Scott, Bart. Volume II, London: Robert Cadell; \& Whittaker \& Company.

Nakiboğlu, M. (2016). Hermann Hesse'nin “Augustus” Masalında Masal Öğeleri Ve Propp'a Göre Çözümlenmesi, Humanitas, 4(8): 241-255.

Özdağ, D. E. (2017). Çağdaş Türk Sanatında Gerçek Dışı Kuş Figürleri, Eğitim ve Toplum Araştırmaları Dergisi/JRES, 4(1): 17-32.

Öztürk, A.O. (2017). Oğuz Tansel Masallarının Derin Kökleri Üzerine Bir Örnek Mavi Gelin Masal1, Turkish Studies, 12(7): 311-322.

Page, R. I. (2009). İskandinav Mitleri, (Çev: İsmail Yılmaz), İstanbul: Phoenix Yayınevi.

Propp, V. J. (1987). Masalların Yapısı ve İncelenmesi, (Çev: Hüseyin Gümüş), Ankara: Kültür ve Turizm Bakanlıği Yayınları.

Sarı, A. Ve A. Ercan, C. (2008). Masalların Psikanalizi, Erzurum: Salkımsöğüt Yayınları.

Senior, W. A. (1995). Stephen R. Donaldson's Chronicles of Thomas Covenant: Variations on the Fantasy Tradition, , Kent, Ohio: The Kent State University Press.

Steinmetz, J.L. (2006). Fantastik Edebiyat, (Çev: Hasan Fehmi Nemli), Ankara: Dost Kitabevi Yayınlar1.

Stockinger, C. und Scherer, S. (2011). Ludwig Tieck: Leben - Werk - Wirkung, Berlin/Boston: Walter de Gruyter GmbH \& Co. KG.

Tieck, J. L. (2004). Elfler, (Çev: Tuğçe Bulgin), İstanbul: Altıkırkbeş Yayın.

Todorov, T. (2004). Fantastik: Edebi Türe Yapısal Bir Yaklaşım, (Çev: Nedret Öztokat), İstanbul: Metis Eleştiri.

Tolkien, J.R.R. (1999). Peri Masalları Üzerine, (Çev: Serap Erincin), İstanbul: Altıkırkbeş Yayin.

Warmer, J. (2012). Die Geschichte von Mittelerde: Die Inoffizielle Anleitung zu den Sprachen, Menschen und Bücher von Mittelerde, Bookcaps Study Guides. 